\title{
Assessment of The Effects of Winter Condition on Sweet Sorghum Yield and Sugar Content
}

\author{
Mohammed Abdalla Elgorashi Bakhite ${ }^{1^{*}}$, Ghazi Hamid Badawi², \\ Alfred Odindo ${ }^{3}$, Lembe Samukelo Magwaza ${ }^{4}$ \\ ${ }^{1}$ Department of Agronomy, Faculty of Agriculture, University of Khartoum, Shambat 13314, Sudan \\ Corresponding author, E-mail: melgorashi@gmail.com, ORCID: https://orcid.org/0000-0001-6631-1619 \\ ${ }^{2}$ Department of Agronomy, Faculty of Agriculture, University of Khartoum, Shambat 13314, Sudan \\ E-mail: ghazibadawi@yahoo.com,ORCID: https://orcid.org/0000-0002-4531-6725 \\ ${ }^{3}$ Discipline of Crop Science, School of Agricultural, Earth and Environmental Sciences, University of KwaZulu-Natal, Private Bag X01, \\ Scottsville, 3209, Pietermaritzburg, South Africa, E-mail: Odindoa@ukzn.ac.za, ORCID: https://orcid.org/0000-0003-1743-4406 \\ ${ }^{3}$ Discipline of Horticultural Science, School of Agricultural, Earth and Environmental Sciences, University of KwaZulu-Natal, Private Bag \\ X01, Scottsville, 3209, Pietermaritzburg, South Africa, E-mail: magwazal@ukzn.ac.za, ORCID: https://orcid.org/0000-0001-9809-2254

\begin{tabular}{l|l}
\hline A R T I C L E I N F O & A B S T R A C T \\
\hline $\begin{array}{l}\text { Research Article } \\
\text { Received : 05/03/2018 } \\
\text { Accepted : 09/11/2018 }\end{array}$ & $\begin{array}{l}\text { Sweet sorghum is an important crop which is produced for food, energy and feed (Almodares and } \\
\text { Hadi, 2009). The crop prefers warm moist soil for germination and emergence. However, it would } \\
\text { be more beneficial if it can be grown in different seasons. A field experiment was carried to } \\
\text { evaluate sixteen sweet sorghum genotypes [Sorghum bicolor (L.) Moench] under winter } \\
\text { conditions in order to assess the possibility of producing the crop throughout the year since the } \\
\text { crop consumes less water and has a short life cycle when compared with sugarcane. The } \\
\text { genotypes we recollected from different areas of Sudan. The experiment was planted using a } \\
\text { Randomized Complete Block Design with three replications. There were significant differences } \\
\text { among genotypes with respect to the number of days to germination, plant height, number of } \\
\text { leaves per plant, chlorophyll content, stem diameter, head weight, shoot fresh weight, head to } \\
\text { shoot ratio, brix value, juice weight and number of days to maturity. A highly positive correlation } \\
(0.92) \text { was observed between juice and shoot weight, and there was a negative correlation (-0.14) } \\
\text { between brix value and head weight. The genotypes showed high variability in all mentioned } \\
\text { parameters, hence, could be useful genetic resources for breeding winter adaptation. }\end{array}$ \\
$\begin{array}{l}\text { Keywords: } \\
\text { Sweet sorghum } \\
\text { Brix } \\
\text { Juice } \\
\text { Maturity }\end{array}$ &
\end{tabular}

(c) (1) () () This work is licensed under Creative Commons Attribution 4.0 International License

\section{Introduction}

Sorghum [Sorghumbicolor (L.) Moench] is an important crop in the Great Plains of Sudan, as well as in many other regions of the world because of its drought resistance, low-input requirements and suitability in crop rotation. Sorghum grow well on wide range of soils but performs best on deep fertile sand loams soils with a $\mathrm{pH}$ 5.0-5.8 (Saballos, 2008; Wright and Turhollow, 2010). The crop is used for food, livestock feed and ethanol production. Some sorghum types are suitable for sugar extraction for ethanol production and the Stover can be used for the manufacture of plastics (Janssen et al., 2010).

Sweet sorghum is used extensively for alcohol production (Kundiyana, 2006; Bulawayo et al., 1996; Smith and Frederiksen, 2000; Gnansounou et al., 2005). Sweet sorghum is an efficient converter of solar energy to high carbohydrate and has high concentration of sugar (Almodares et al., 2008).

Sweet sorghums are distributed in the sorghum growing areas of Africa and India (Ramadan, 2011). Studies on sweet sorghum world collection, documented at ICRISAT (The International Crops Research Institute for semi- Arid Tropics), showed that sweet stalk sorghum types are widely distributed in Botswana, Cameron, Chad. Ethiopia, Kenya, Malawi, Niger, Sudan, U.S.A., Zambia and Zimbabwe (Damon, 1962).

Studies on the potential use of sweet sorghum as raw material for ethanol in the USA and Europe started in the 70`s and 80`s, respectively (Tsuchihashi and Goto, 2004). In recent years, there has been increased interest in the use of sweet sorghum for ethanol production in India, Philippines, China and USA (Godoy, 2011). The sugars present in the stalk of sweet sorghum can be fermented and converted to ethanol using relatively simple techniques (Smith and Reeves Jr., 1981; Hill et al., 1987; Smith et al., 1987).

Generally, Sorghum is tolerant to drought, water logging, salinity, soil infertility and high temperature. Sweet sorghum has wider adaptability, rapid growth and high sugar accumulation associated with high biomass production in the semi-arid tropics (Smith et al., 1987). 
Therefore, sweet sorghum is a good alternative crop to sugar cane since it requires only one third of the amount of water that sugar cane needs. Sorghum matures in 100120 days, while first sugar cane crop takes one year to mature. Similarly, on volume basis, sweet sorghum has higher sugar content compared to sugarcane (Almodares et al., 2008). It can be cultivated in temperate and subtropical climates.

Sweet sorghum carbohydrates are stored in the stalk, with sugar concentrations of 8-20\% (Rains et al., 1989). In Louisiana U.S.A., stalk sugar concentration was recorded at 8.3 to $14.0 \%$ during flowering and 12.8 to16.6\% during the soft dough stage (Wortmann and Regassa, 2011). Considerable progress has been made in breeding improved sweet sorghum lines with higher mill able cane and juice yield in India (Reddy et al., 2008). The International Crops Research Institute for semi- Arid Tropics (ICRISAT) has developed several improved lines with high stalk sugar content and a few of these lines are being tested in pilot studies for sweet sorghum-based ethanol production in India, Philippines and Uganda.

In Sudan sweet sorghum is grown in areas South of Gadarif, Blue Nile area, Senar, Gezira White Nile, Kurdfan and Darfur. In these areas it is mainly used for chewing. The crop is adapted to a wide range of soil $\mathrm{pH}$ (5.0-8.5). The suitable temperature for growth is about $28^{\circ} \mathrm{C}$.

Although sorghum is more tolerant to cool temperatures than other warm-loving cereals, it is still sensitive to temperatures lower than $15^{\circ} \mathrm{C}$. These temperatures occur in the Great Plains primarily during germination and early stages.

Some studies have shown that cold-tolerant sorghum cultivars had requires temperatures 6 to $10^{\circ} \mathrm{C}$ less than those of cold-susceptible ones and they maintain respiration rates that are 20 to $25 \%$ higher. The limiting factor for sorghum production in the temperate Zone is the vulnerability to low temperatures (Bacon et al., 1986; Tiryaki and Andrews, 2001).

Although low temperatures may reduce the carrying capacity of the phloem of sorghum this unlikely to be an important factor in regulating plant growth at low temperatures (Wardlaw and Bagnall, 1981). Low temperatures throughout the growing season lengthen the growth cycle of genotypes and delay flowering (Zinn et al., 2010). Osuna-Ortega et al. (2003) found that the effect of genotypes, environment and their interaction were highly significant. Quinby et al. (1973) and Zinn et al. (2010) showed that cold stress often delays phonological development (flowering and maturity). Cold stress causes spikelet sterility, flower abortion and reduction in the number of pollen grains intercepted by the stigma in several crop species resulting in poor seed-set and ultimately low grain yield (Khan et al., 1986; Singh, 1985; Maulana and Tesso, 2013; Lee, 2001; Gunawardena et al., 2003; Oliver et al., 2005; Thakur et al., 2010). Moreover, tremendous yield losses due to cold temperature stress on major grain crops have also been reported in sub-tropical and temperate regions (Thakur et al., 2010). The most visible effect of cold temperature early in the season seems to be on the establishment of the crop. Reports from earlier studies showed that germination, emergence and seedling vigor are highly compromised when the crop is subjected to the stress early in the season (Pinthus and Rosenblum, 1961; Singh, 1985; Prasad et al., 2006; Prasad et al., 2008). These reports are substantiated by more recent studies where the effect of early-season cold stress has been noted to reduce plant population with the effect being variable between genotypes (Tiryaki and Andrews, 2001; Franks et al., 2006). Low soil temperature during early growing season severely reduces germination, emergence and seedling growth (Franks at al., 2006). Maulana (2011); Burow et al. (2011); Patanè et al. (2012); Kapanigowda et al. (2013) found that seedling height, leaf chlorophyll content, days to flowering and days to maturity were also significantly affected by the early season cold stress. However, overall number of leaves per plant and plant height were not affected by early stress therefore, is need to screen different genotypes for cold tolerance, yield and yield attributes including sugar content. The development of hybrids with increased cold tolerance and early plant growth would create sweet sorghum production adapted to wider range of climatic conditions.

Sorghum hybrids with improved cold tolerance will not only result in increased yield but also lead to expansion of sorghum production into areas traditionally considered too cold for the crop. This will also enhance yield by allowing early planting in current production areas and 3-4 cultivation seasons. Assessment of the ultimate effects of both early and mid-season cold temperature stress is important to justify investment for improvement of the trait.

There, the objective of this study was to evaluate local sweet sorghum genotypes from different areas of Sudan and assess the effects of winter season cold stress on their yield performance and sugar content.

\section{Materials and Methods}

\section{Experimental Site and Plant Materials}

A field experiment was conducted at the Demonstration Farm, Faculty of Agriculture, University of Khartoum, Shambat, to evaluate the performance of sixteen genotypes of sweet sorghum [Sorghum bicolor (L.) Moench]. The farm is located in semi desert zone (Latitude $15^{\circ} 39^{\prime} \mathrm{N}$, longitude $32^{\circ} 31^{\prime} \mathrm{E}$ and altitude $380 \mathrm{~m}$ above sea level). The soil of the experimental site is heavy clay with alkaline $\mathrm{pH}$. Average, minimum and maximum temperatures range between $14^{\circ} \mathrm{C}$ and $27^{\circ} \mathrm{C}$ during the winter season and between $25^{\circ} \mathrm{C}$ and $41^{\circ} \mathrm{C}$ during the summer season. The relative humidity ranges between $31 \%$ and $51 \%$ during the wet month of the year. Data on the temperature and relative humidity were recorded during the experimental period. The planting material used in this study consisted of sixteen genotypes collected from different areas of Sudan, they are: BE, RNF 1107, RagbtDohElbeit H, Barshoom 1, RagbtDohElbeit K, KB103, Nyala, Barshoom 2, Zakaria 4, NF1100, KBK1101, G1121, Junina, WNB105, Elroseiris, WNBK.

\section{Land Preparation and Planting}

The field was disc ploughed, disc harrowed, levelled and ridged (70 cm spacing between ridges). The design of the experiment was randomized complete block design 
(RCBD) with three replications. Each of the sixteen genotypes was planted in two ridges of $4 \mathrm{~m}$ length. The genotypes were planted for one season in winter 2012. The crop was irrigated immediately after sowing and then every ten days during the experimental period. Weeding was done manually at 30 days and then 50 days. The pesticide Furadan (carbofuradan) was applied for the control of stem borers (Chilo sp.). Urea $(46 \% \mathrm{~N})$ was applied at a rate of $21.6 \mathrm{~kg} / \mathrm{ha}$ at 37 days from sowing and $21.6 \mathrm{~kg} / \mathrm{ha}$ at 60 days from sowing.

\section{Data Collection}

Five plants were randomly selected and tagged from each genotype to study the following parameters. Data was collected on mean emergence time (MET) in days, and final emergence $(\%)$. Plant height $(\mathrm{cm})$ was measured four times by using ruler at 36, 54, 64 and 84 days after sowing. Stem diameter $(\mathrm{cm})$ at milk stage by using digital Vernier number of days to harvest were also recorded. In addition to these, the following yield and yield-related traits were also recorded.

Chlorophyll content (SPAD unit) it was measured on flag leaf 45, 71, 77 and 96 days after sowing, using portable chlorophyll meter (SPAD, Konica Minolta, Japan). Head weight (g) and shoot fresh weight (g) were recorded at milk stage. Head to shoot ratio was calculated and brix value measured two times at anthesis for the third internodes from the top of the plants for three randomly selected plants and then at milk stage from three randomly selected plants out of the five selected plants after juice extraction using Sugar Cane Presser. Model NO ET-ZZJ80. Brix was measured using a hand refractometer (ATAGO R-Japan). Juice weight was recorded as the average of juice extracted from three plants using Sugar Cane Presser. Model NO ET-ZZJ80.

\section{Statistical Analysis}

Analysis of variance (ANOVA) was performed on the data according to the method described by Gomez and Gomez (1984) for a randomized complete block design. Means were then separated using Duncan's Multiple
Range Test (DMRT). Simple linear correlation coefficient was estimated between juice weight, head weight, fresh weight, brix value and chlorophyll content measured at the milk stage.

\section{Results}

Significant differences $(\mathrm{P}<0.05)$ in number of days to germination were observed among the genotypes. The highest mean number of days to emergence (5.66) was scored on BE, RagbtDohElbeit K, KB 103, Nyala, NF 1100 and WNBK. The lowest means number of days to germination (5.00) was scored on RNF 1107, RagbtDohElbeit H, Barshoom 1, Barshoom 2, Zakaria 4, KBK1101, G 1121, Junina,WNB 105 and Elroseiris (Table 1).

Significant differences in plant height were shown among the genotypes. Highest mean plant heights were $34.46,113.73,158.1$ and $173.6 \mathrm{~cm}$ for sample taken 35 50,65 and 80 days after sowing and were scored by Elroseiris, Zakaria 4 and G1121, WNB105 and RNF1107, respectively. Whereas the lowest means plant height was 19.06, 71.87, 121.63 and $134.40 \mathrm{~cm}$ scored by RagbtDohElbeit K, B E, RagbtDohElbeit K and Junina, respectively for the same sampling occasions. At 84 days after sowing most of the genotypes scored more or less the same mean plant height albeit the significantly different plant height at earlier stages (Table 2).

Statistical analysis showed significant differences among the genotypes in chlorophyll content at all sampling occasions. The highest chlorophyll content, 56.93, 60.00, 61.26, and 54.83 were scored on Elroseiris, Elroseiris, Barshoom2 and Barshoom2, respectively for samples taken at 45, 71, 77 and 96 days after sowing, respectively. The lowest values of the same parameter were $40.00,51.10,50.33$ and 43.26 recorded for RNF1107, KBK1101, KBK 1101 and WNB 105, respectively for the same sampling occasions. Most of the genotypes showed lower chlorophyll content at 96 days after sowing compared to the earlier samples (Table 3).

Table 1 Mean emergence time of sixteen sweet sorghum genotypes sown in season 2012/2013

\begin{tabular}{l|c}
\hline \multicolumn{1}{c|}{ Genotypes } & Number of days to germination \\
\hline B E & $5.66^{\mathrm{a}}$ \\
RNF1107 & $5.00^{\mathrm{b}}$ \\
RagbtDohElbeit H & $5.00^{\mathrm{b}}$ \\
Barshoom 1 & $5.00^{\mathrm{b}}$ \\
RagbtDohElbeit K & $5.66^{\mathrm{a}}$ \\
KB103 & $5.66^{\mathrm{a}}$ \\
Nyala & $5.66^{\mathrm{a}}$ \\
Barshoom 2 & $5.00^{\mathrm{b}}$ \\
Zakaria 4 & $5.00^{\mathrm{b}}$ \\
NF1100 & $5.66^{\mathrm{a}}$ \\
KBK1101 & $5.00^{\mathrm{b}}$ \\
G1121 & $5.00^{\mathrm{b}}$ \\
Junina & $5.00^{\mathrm{b}}$ \\
WNB105 & $5.00^{\mathrm{b}}$ \\
Elroseiris & $5.00^{\mathrm{b}}$ \\
WNBK & $5.66^{\mathrm{a}}$ \\
\hline Means followed by the same letter are not significantly different at $\mathrm{P}<0.05$ according to Dunant's Multiple Range Test
\end{tabular}

Means followed by the same letter are not significantly different at $\mathrm{P}<0.05$ according to Dunant's Multiple Range Test 
Table 2 Mean plant height $(\mathrm{cm})$ of sixteen sweet sorghum genotypes at 35, 50, 65 and 80 days sown in season 2012/2013

\begin{tabular}{|c|c|c|c|c|}
\hline \multirow{2}{*}{ Genotypes } & \multicolumn{4}{|c|}{ Plant height (days after sowing) } \\
\hline & 35 days & 50 days & 65 days & 80 days \\
\hline B E & $22.26^{\mathrm{bc}}$ & $71.87^{\mathrm{c}}$ & $124.20^{\mathrm{bc}}$ & $151.76^{\mathrm{a}}$ \\
\hline RNF 1107 & $22.67^{\mathrm{bc}}$ & $75.27^{\mathrm{bc}}$ & $148.667^{\mathrm{a}}$ & $173.6^{\mathrm{a}}$ \\
\hline RagbtDohElbeit H & $26.46^{\mathrm{abc}}$ & $104.53^{\mathrm{abc}}$ & $137.73^{\mathrm{abc}}$ & $144.7^{\mathrm{a}}$ \\
\hline Barshoom 1 & $28.13^{\mathrm{abc}}$ & $103.40^{\mathrm{abc}}$ & $143.667^{\mathrm{abc}}$ & $153.2^{\mathrm{a}}$ \\
\hline RagbtDohElbeit K & $19.06^{\mathrm{c}}$ & $97.53^{\mathrm{abc}}$ & $121.63^{\mathrm{c}}$ & $136.7^{\mathrm{b}}$ \\
\hline KB103 & $30.40^{\mathrm{ab}}$ & $88.20^{\mathrm{abc}}$ & $139.30^{\mathrm{abc}}$ & $139.97^{\mathrm{a}}$ \\
\hline Nyala & $24.40^{\mathrm{bc}}$ & $81.50^{\mathrm{abc}}$ & $145.73^{\mathrm{ab}}$ & $158.3^{\mathrm{a}}$ \\
\hline Barshoom 2 & $22.66^{\mathrm{bc}}$ & $82.43^{\mathrm{abc}}$ & $135.76^{\mathrm{abc}}$ & $144.73^{\mathrm{a}}$ \\
\hline Zakaria 4 & $30.60^{\mathrm{ab}}$ & $113.73^{\mathrm{a}}$ & $142.06^{\mathrm{abc}}$ & $151.33^{\mathrm{a}}$ \\
\hline KBK1101 & $22.73^{\mathrm{bc}}$ & $77.43^{\mathrm{abc}}$ & $146.53^{\mathrm{ab}}$ & $152.03^{\mathrm{a}}$ \\
\hline NF1100 & $31.66^{\mathrm{ab}}$ & $113.63^{\mathrm{a}}$ & $147.46^{\mathrm{a}}$ & $146.37^{\mathrm{a}}$ \\
\hline G1121 & $31.53^{\mathrm{ab}}$ & $113.73^{\mathrm{a}}$ & $138.53^{\mathrm{abc}}$ & $152.97^{\mathrm{a}}$ \\
\hline Junina & $22.93^{b c}$ & $74.40^{\mathrm{bc}}$ & $124.43^{\mathrm{bc}}$ & $134.4^{\mathrm{b}}$ \\
\hline WNB105 & $24.73^{b c}$ & $79.33^{\mathrm{abc}}$ & $158.10^{\mathrm{a}}$ & $173.53^{\mathrm{a}}$ \\
\hline Elroseiris & $34.46^{\mathrm{a}}$ & $110.67^{\mathrm{ab}}$ & $141.80^{\mathrm{abc}}$ & $142.83^{\mathrm{a}}$ \\
\hline WNBK & $26.33^{\mathrm{abc}}$ & $79.7^{\mathrm{abc}}$ & $140.00^{\mathrm{abc}}$ & $150.8^{\mathrm{a}}$ \\
\hline
\end{tabular}

Means followed by the same letter are not significantly different at $\mathrm{P}<0.05$ according to Dunant's Multiple Range Test

Table 3 Mean chlorophyll content of sixteen sweet sorghum genotypes sampled at 45, 71, 77 and 96 days from sowing sown in season 2012/2013

\begin{tabular}{|c|c|c|c|c|}
\hline \multirow{2}{*}{ Genotypes } & \multicolumn{4}{|c|}{ Chlorophyll content } \\
\hline & 45 days after sowing & 71 days after sowing & 77 days after sowing & 96 days after sowing \\
\hline B E & $52.30^{\mathrm{ab}}$ & $53.60^{\text {bcd }}$ & $53.00^{\text {cbd }}$ & $48.76^{\mathrm{abc}}$ \\
\hline RNF1107 & $40.00^{c}$ & $52.83^{\mathrm{cd}}$ & $55.36^{\mathrm{abcd}}$ & $50.20^{\mathrm{abc}}$ \\
\hline RagbtDohElbeit $\mathrm{H}$ & $52.26^{\mathrm{ab}}$ & $58.26^{\mathrm{abc}}$ & $57.80^{\mathrm{abcd}}$ & $46.13^{\mathrm{abc}}$ \\
\hline Barshoom 1 & $48.80^{\mathrm{abc}}$ & $59.56^{\mathrm{ab}}$ & $58.86^{\mathrm{abc}}$ & $50.90^{\mathrm{abc}}$ \\
\hline RagbtDohElbeit K & $47.10^{\mathrm{bc}}$ & $57.20^{\mathrm{abcd}}$ & $55.90^{\mathrm{abcd}}$ & $50.40^{\mathrm{abc}}$ \\
\hline KB103 & $50.83^{a b c}$ & $53.36^{\mathrm{cd}}$ & $51.60^{\mathrm{cd}}$ & $47.86^{\mathrm{abc}}$ \\
\hline Nyala & $50.33^{a b c}$ & $56.80^{\mathrm{abcd}}$ & $59.56^{\mathrm{abc}}$ & $44.86^{\mathrm{cb}}$ \\
\hline Barshoom 2 & $51.40^{\mathrm{abc}}$ & $58.66^{\mathrm{abc}}$ & $61.26^{\mathrm{a}}$ & $54.83^{\mathrm{a}}$ \\
\hline Zakaria 4 & $51.93^{\mathrm{abc}}$ & $58.63^{\mathrm{abc}}$ & $51.80^{\mathrm{cd}}$ & $53.53^{a b}$ \\
\hline NF1100 & $49.96^{\mathrm{abc}}$ & $58.63^{\mathrm{abc}}$ & $53.73^{\mathrm{abcd}}$ & $45.16^{\mathrm{cb}}$ \\
\hline KBK1101 & $51.73^{a b c}$ & $51.10^{\mathrm{d}}$ & $50.33^{\mathrm{d}}$ & $43.46^{\mathrm{c}}$ \\
\hline G1121 & $52.26^{\mathrm{ab}}$ & $55.33^{\mathrm{abcd}}$ & $54.83^{\mathrm{abcd}}$ & $50.23^{\mathrm{abc}}$ \\
\hline Junina & $47.40^{\mathrm{bc}}$ & $56.36^{\mathrm{abcd}}$ & $59.03^{\mathrm{abcd}}$ & $49.93^{\mathrm{abc}}$ \\
\hline WNB 105 & $48.20^{\mathrm{bc}}$ & $55.70^{\mathrm{abcd}}$ & $55.30^{\mathrm{abcd}}$ & $43.26^{c}$ \\
\hline Elroseiris & $56.93^{\mathrm{a}}$ & $60.00^{\mathrm{a}}$ & $60.60^{\mathrm{ab}}$ & $50.36^{\mathrm{abc}}$ \\
\hline WNBK & $43 . b^{c}$ & $55.06^{\mathrm{abcd}}$ & $53.46^{\mathrm{abcd}}$ & $50.06^{\mathrm{abc}}$ \\
\hline
\end{tabular}

Means followed by the same letter are not significantly different at $\mathrm{P}<0.05$ according to Dunant's Multiple Range Test

The result of analysis of variance showed significant differences among genotypes in stem diameter. The highest mean (1.33) was obtained by Zakaria 4, whereas the lowest mean (0.94) obtained by RNF 1107 . WNB105 and RNF1107 produced significantly lower stem diameter compared to other genotypes (Table 4).

The differences among the genotypes on shoot weight (g), head weight ( $\mathrm{g}$ ) and head to shoot ratio revealed by the analysis of variance were significant. The highest mean shoot weight (235.37 g) was obtained by Barshoom 1 , the lowest mean (97.63 g) was obtained by WNB105 (Table 4). The highest mean head mass (81.2 g) was obtained by Barshoom 1, while the lowest mean (25.26 g) was obtained by Elroseiris (Table 4). The highest mean head to shoot ratio (0.41) was obtained by Barshoom 2, while the lowest mean (0.16) was obtained from RagbtDohElbeit K (Table 4).
The analysis of variance showed significant differences among genotypes on brix value at anthesis and milk stage. At anthesis the genotype Elroseiris was scored the highest brix value (12.23) while at milk stage the highest value (17.66) was scored by RNF1107. At milk stage all genotypes produced higher value compared to the value at anthesis (Table 5).

Statistical analysis showed significant differences among the sweet sorghum genotypes for juice weight. The highest mean juice weight $(54.73 \mathrm{~g})$ was obtained by WNBK; however the lowest mean (3.1 g) was obtained by WNB105. WNBK produced significantly higher juice weight compared to other genotypes except Barshoom1 (Table 6).

Analysis of variance showed significant differences in the number of days to harvest among the genotypes. The highest mean number of days to harvest (93) was scored by Nyala and NF1100, and the lowest mean value (88.66) was obtained by Elroseiris (Table 6). 
Table 4. Mean stem diameter, shoot mass (g), head mass ( $\mathrm{g}$ ) and head to shoot ratio of sixteen sweet sorghum genotypes sown in season 2012/2013

\begin{tabular}{|c|c|c|c|c|}
\hline Genotypes & Stem diameter $(\mathrm{cm})$ & Shoot mass $(\mathrm{g})$ & Head mass $(\mathrm{g})$ & Head to Shoot ratio \\
\hline B E & $1.08^{\mathrm{abc}}$ & $147.00^{\text {bcde }}$ & $38.40^{\text {cde }}$ & $0.25^{\mathrm{bcd}}$ \\
\hline RNF 1107 & $0.94^{\mathrm{c}}$ & $161.67^{\mathrm{bcd}}$ & $38.33^{\text {cde }}$ & $0.24^{\mathrm{bcd}}$ \\
\hline RagbtDohElbeit H & $1.13^{\mathrm{abc}}$ & $157.77^{\text {bcde }}$ & $37.96^{\text {cde }}$ & $0.27^{\mathrm{abcd}}$ \\
\hline Barshoom 1 & $1.20^{\mathrm{abc}}$ & $235.37^{\mathrm{a}}$ & $81.20^{\mathrm{a}}$ & $0.34^{\mathrm{abc}}$ \\
\hline RagbtDohElbeit K & $1.16^{\mathrm{abc}}$ & $151.83^{\text {bcde }}$ & $26.00^{\mathrm{de}}$ & $0.16^{\mathrm{d}}$ \\
\hline KB103 & $1.15^{\mathrm{abc}}$ & $121.73^{\mathrm{def}}$ & $44.30^{\mathrm{bcd}}$ & $0.36^{\mathrm{ab}}$ \\
\hline Nyala & $1.06^{\mathrm{abc}}$ & $179.27^{\mathrm{b}}$ & $60.26^{\mathrm{b}}$ & $0.33^{\mathrm{abc}}$ \\
\hline Barshoom 2 & $1.21^{\mathrm{abc}}$ & $130.43^{\text {cdef }}$ & $50.20^{\mathrm{bc}}$ & $0.41^{\mathrm{a}}$ \\
\hline Zakaria 4 & $1.33^{\mathrm{a}}$ & $151.73^{\text {bcde }}$ & $45.86^{\mathrm{bc}}$ & $0.30^{\mathrm{abcd}}$ \\
\hline NF1100 & $1.10^{\mathrm{abc}}$ & $134.87^{\text {bcdef }}$ & $39.86^{\text {cde }}$ & $0.28^{\mathrm{abcd}}$ \\
\hline KBK1101 & $1.17^{\mathrm{abc}}$ & $171.50^{\mathrm{bc}}$ & $51.26^{\mathrm{bc}}$ & $0.29^{\mathrm{abcd}}$ \\
\hline G1121 & $1.13^{\mathrm{abc}}$ & $133.87^{\text {cdef }}$ & $36.96^{\text {cde }}$ & $0.27^{\mathrm{bcd}}$ \\
\hline Junina & $1.04^{\mathrm{abc}}$ & $114.00^{\mathrm{ef}}$ & $35.43^{\text {cde }}$ & $0.30^{\mathrm{abcd}}$ \\
\hline WNB105 & $1.03^{\mathrm{bc}}$ & $97.63^{\mathrm{f}}$ & $35.76^{\text {cde }}$ & $0.30^{\mathrm{abcd}}$ \\
\hline Elroseiris & $1.10^{\mathrm{abc}}$ & $120.87^{\mathrm{def}}$ & $25.26^{\mathrm{e}}$ & $0.20^{\mathrm{cd}}$ \\
\hline WNBK & $1.30^{\mathrm{ab}}$ & $226.63^{\mathrm{a}}$ & $48.13^{\mathrm{bc}}$ & $0.21^{\mathrm{cd}}$ \\
\hline
\end{tabular}

Means followed by the same letter are not significantly different at $\mathrm{P}<0.05$ according to Dunant's Multiple Range Test

Table 5 Mean brix value of sixteen sweet sorghum genotypes sampled at anthesis and milk stage sown in season 2012/2013

\begin{tabular}{|c|c|c|}
\hline \multirow{2}{*}{ Genotypes } & \multicolumn{2}{|c|}{ Brix value } \\
\hline & at Anthesis & at Milk stage \\
\hline B E & $7.66^{\mathrm{bc}}$ & $12.83^{\mathrm{abc}}$ \\
\hline RNF 1107 & $10.33^{\mathrm{ab}}$ & $17.66^{\mathrm{a}}$ \\
\hline RagbtDohElbeit H & $8.43^{a b c}$ & $13.66^{\mathrm{abc}}$ \\
\hline Barshoom 1 & $11.43^{\mathrm{ab}}$ & $12.33^{\mathrm{abc}}$ \\
\hline RagbtDohElbeit K & $7.83^{\mathrm{bc}}$ & $12.66^{\mathrm{abc}}$ \\
\hline KB103 & $7.73^{\mathrm{bc}}$ & $8.66^{\mathrm{cd}}$ \\
\hline Nyala & $7.83^{\mathrm{bc}}$ & $12.33^{\mathrm{abc}}$ \\
\hline Barshoom 2 & $8.50^{\mathrm{abc}}$ & $14.66^{\mathrm{ab}}$ \\
\hline Zakaria 4 & $11.00^{\mathrm{ab}}$ & $11.66^{\mathrm{bcd}}$ \\
\hline NF1100 & $7.33^{\mathrm{bc}}$ & $9.33^{\mathrm{bcd}}$ \\
\hline KBK1101 & $5.43^{\mathrm{c}}$ & $6.66^{\mathrm{d}}$ \\
\hline G1121 & $9.66^{\mathrm{abc}}$ & $11.66^{\mathrm{bcd}}$ \\
\hline Junina & $9.00^{\mathrm{abc}}$ & $10.50^{\mathrm{bcd}}$ \\
\hline WNB105 & $8.33^{\mathrm{abc}}$ & $9.33^{\mathrm{bcd}}$ \\
\hline Elroseiris & $12.23^{\mathrm{a}}$ & $12.83^{\mathrm{abc}}$ \\
\hline WNBK & $9.93^{\mathrm{ab}}$ & $13.16^{\mathrm{abc}}$ \\
\hline
\end{tabular}

Means followed by the same letter are not significantly different at $\mathrm{P}<0.05$ according to Dunant's Multiple Range Test

Table 6. Mean juice weight (g) and number of days to harvest of sixteen sweet sorghum genotypes sown in season 2012/2013

\begin{tabular}{l|cc}
\hline \multicolumn{1}{c}{ Genotypes } & Juice weight $(\mathrm{g})$ & Time to harvest \\
\hline B E & $27.63^{\mathrm{c}}$ & $89.00^{\mathrm{ab}}$ \\
RNF 1107 & $28.63^{\mathrm{c}}$ & $90.33^{\mathrm{ab}}$ \\
RagbtDohElbeit H & $31.96^{\mathrm{bc}}$ & $90.33^{\mathrm{ab}}$ \\
Barshoom 1 & $46.10^{\mathrm{ab}}$ & $91.33^{\mathrm{ab}}$ \\
RagbtDohElbeit K & $26.03^{\mathrm{c}}$ & $90.66^{\mathrm{ab}}$ \\
KB103 & $20.20^{\mathrm{c}}$ & $91.33^{\mathrm{ab}}$ \\
Nyala & $33.40^{\mathrm{bc}}$ & $93.00^{\mathrm{a}}$ \\
Barshoom 2 & $30.50^{\mathrm{bc}}$ & $90.33^{\mathrm{ab}}$ \\
Zakaria 4 & $30.06^{\mathrm{c}}$ & $90.33^{\mathrm{ab}}$ \\
NF1100 & $19.53^{\mathrm{c}}$ & $93.00^{\mathrm{a}}$ \\
KBK1101 & $26.76^{\mathrm{c}}$ & $90.00^{\mathrm{ab}}$ \\
G1121 & $22.66^{\mathrm{c}}$ & $92.33^{\mathrm{ab}}$ \\
Junina & $16.63^{\mathrm{dc}}$ & $89.33^{\mathrm{ab}}$ \\
WNB105 & $3.10^{\mathrm{d}}$ & $92.00^{\mathrm{ab}}$ \\
Elroseiris & $22.76^{\mathrm{c}}$ & $88.66^{\mathrm{b}}$ \\
WNBK & $54.73^{\mathrm{a}}$ & $91.00^{\mathrm{ab}}$ \\
\hline
\end{tabular}

Means followed by the same letter are not significantly different at $\mathrm{P}<0.05$ according to Dunant's Multiple Range Test 
Correlations Between Juice Weight, Head Mass, Shoot Mass, Brix Value and Chlorophyll Content

The result showed that there were positive correlations between above mentioned attributes at milk stage, and there was a highly positive correlation (0.92) between juice and shoot weight. However there were negative correlations between head weight and chlorophyll content $(-0.23)$ and between head weight and brix value $(-0.14)$.

Table 7 Correlation coefficients between juice weight, head mass, shoot weight, brix value and chlorophyll content of sixteen sweet sorghum genotypes sown in season 2012/2013

\begin{tabular}{l|cccc}
\hline \multicolumn{1}{c|}{ Parameter } & Juice weight & Chlorophyll content & Shoot weight & Head weight \\
\hline Chlorophyll content & 0.363 & & & \\
Shoot weight & 0.92 & 0.105 & & \\
Head weight & 0.102 & -0.23 & 0.15 & -0.14 \\
Brix value & 0.415 & 0.570 & 0.24 & -14 \\
\hline
\end{tabular}

\section{Discussion}

Cold season affected the growth and yield performance of sweet sorghum. In this study, there were significant differences among sweet sorghum genotypes in all parameters studied. The genotypes showed significant differences in number of days to emergence. This could be attributed to the effect of low temperature on emergence. Similar results were reported by Franks et al. (2006) they found that low soil temperature during early growing season can severely reduce emergence. The variable response of the genotypes to low temperature observed in this study might be attributed to the genetic background of each genotype since they were collected from different locations. During the winter there was a significant effect on plant height of sweet sorghum genotypes. This might be due to genetic factors. This result is disagreeing with Burow et al. (2011) who reported that the response of genotypes under cold stress was not significant. The genotypes showed significant differences in number of days to harvest. This might be attributed to the effect of temperature on the developmental stages of sweet sorghum. Similar results were reported by Zinn et al. (2010) who found that low temperatures throughout the growing season lengthen the growth cycle of genotypes and cause delay in flowering. Similarly Maulana (2011) showed that number of days to maturity was significantly affected by the early season cold stress.

Further, there were significant differences among genotypes with respect to chlorophyll content. Similar results were reported by Kapanigowda et al. (2013) who reported that leaf chlorophyll content significantly affected by the early season cold stress. The significant differences among the genotypes found in this study, might be due to the fact that the genotypes differ in their adaptability to low temperature. However, Wardlaw and Bagnall (1981) indicated that low temperatures are unlikely to be an important factor in regulating plant growth. In this study, there were significant differences in head mass $(\mathrm{g})$, shoot fresh mass and head to shoot ratio at milk stage. These differences might be due to fact that these genotypes had different growth responses that lead to different dry matter accumulation. This finding is in line with the finding of Burow et al. (2011) who found that genotypes had significantly variable yield components.

The significant differences in Brix value and juice weight might be due to the differences in genetic factors as a main reason which it can effect on growth parameters and dry matter accumulation and finally Brix value. The differences in Brix value between anthesis and milk stage is because Brix value increases with plant development. Similar results were reported by Reddy et al. (2008) as they found that Brix and starch increased with advancement of the growth stage. Concerning juice weight, it also increased at milk stage, this result is similar to the finding of Almodares et al. (2008). Those workers observed that syrup yield was maximized by harvesting during the late milk to hard dough stage. Similar results were also reported by Rains et al. (1989) whom indicated that sugar yield is dependent on length of growing season and the amount of radiation intercepted.

\section{Conclusions}

Sweet sorghum genotypes significantly differed in all parameters measured. These genotypes will be good source for breeding programs.

The results also showed that there was a highly positive correlation (0.92) between juice weight and shoot weight, and a negative correlation between brix value and head weight.

Since this experiment was conducted for only one season, it's recommended that more seasons and locations should be used to obtain more reliable results.

\section{References}

Almodares A, Hadi M. 2009. Production of bioethanol from sweet sorghum: A review. African Journal of Agricultural Research, 4: 772-780.

Almodares A, Taheri R, Adeli S. 2008. Stalk yield and carbohydrate composition of sweet sorghum [Sorghum bicolor (L.) Moench] cultivars and lines at different growth stages. J. Malesian Appl. Biol, 37: 31-36.

Bacon R, Cantrell R, Axtell J. 1986. Selection for seedling cold tolerance in grain sorghum. Crop science, 26: 900-903.

Bulawayo B, Bvochora J, Muzondo M. Zvauya R. 1996. Ethanol production by fermentation of sweet-stem sorghum juice using various yeast strains. World journal of Microbiology and Biotechnology, 12: 357-360.

Burow G, Burke JJ, Xin Z, Franks CD. 2011. Genetic dissection of early-season cold tolerance in sorghum (Sorghum bicolor (L.) Moench). Molecular Breeding, 28: 391-402.

Damon E. 1962. The cultivated sorghums of Ethiopia. Project report. Imperial Ethiopian College of Agriculture and Mechanical Arts, Ethiopia. 
Franks CD, Burow GB, Burke JJ. 2006. A comparison of US and Chinese sorghum germplasm for early season cold tolerance. Crop science, 46: 1371-1376.

Gnansounou E, Dauriat A, Wyman C. 2005. Refining sweet sorghum to ethanol and sugar: economic trade-offs in the context of North China. Bioresource technology, 96: 9851002.

Godoy JGV. 2011. Sorghum Improvement as Biofuel Feedstock: Juice Yield, Sugar Content and Lignocellulosic Biomass. Kansas State University.

Gomez KA, Gomez AA. 1984. Statistical procedures for agricultural research, John Wiley \& Sons.

Gunawardena T, Fukai S, Blamey F. 2003. Low temperature induced spikelet sterility in rice. I. Nitrogen fertilisation and sensitive reproductive period. Crop and Pasture Science, 54: 937-946.

Hill N, Posler G, Bolsen K. 1987. Fermentation inhibition of forage and sweet sorghum silages treated with acrylic or maleic acid. Agronomy journal, 79: 619-623.

Janssen R, Rutz D, Braconnier S, Reddy B, RAO S, Schaffert R, Parella R, Zaccharias A, Rettenmaier N, Reinhardt G. 2010. Sweet sorghum-an alternative energy crop. Environments, 4,6 .

Kapanigowda MH, Perumal R, Aiken RM, Herald TJ, Bean SR, Little CR. 2013. Analyses of sorghum [Sorghum bicolor (L.) Moench] lines and hybrids in response to early-season planting and cool conditions. Canadian Journal of Plant Science, 93: 773-784.

Khan D, Mackill D, Vergara B. 1986. Selection for tolerance to low temperature-induced spikelet sterility at anthesis in rice. Crop Science, 26: 694-698.

Kundiyana DK. 2006. "Sorganoli $(R)^{\prime}$ : In-field Production of Ethanol from Sweet Sorghum. Oklahoma State University.

Lee MH. 2001. Low temperature tolerance in rice: the Korean experience. Aciar Proceedings, 2001. ACIAR, 1998: 109117.

Maulana F. 2011. Analysis of cold tolerance in sorghum [Sorghum bicolor (L.) Moench]. Kansas State University.

Maulana F, Tesso TT. 2013. Cold temperature episode at seedling and flowering stages reduces growth and yield components in sorghum. Crop Science, 53: 564-574.

Oliver SN, Van Dongen JT, Alfred SC, Mamun EA, Zhao X, Saini HS, Fernandes SF, Blanchard CL, Sutton BG, Geigenberger P. 2005. Cold-induced repression of the rice anther-specific cell wall invertase gene OSINV4 is correlated with sucrose accumulation and pollen sterility. Plant, Cell \& Environment, 28: 1534-1551.

Osuna-Ortega J, Mendoza-Castillo MDC, Mendoza-Onofre L. 2003. Sorghum cold tolerance, pollen production. Maydica, 48: 125-132.

Patanè C, Saita A, Tubeileh A. 2012. Seedling emergence response to early sowings in unprimed and osmoprimed seeds of fiber sorghums for energy biomass under semi-arid climate. Italian Journal of Agronomy, 7, 30.

Pinthus MJ, Rosenblum J. 1961. Germination and seedling emergence of sorghum at low temperatures. Crop Science, 1: 293-296.
Prasad PV, Boote KJ, Allen LH. 2006. Adverse high temperature effects on pollen viability, seed-set, seed yield and harvest index of grain-sorghum [Sorghum bicolor (L.) Moench] are more severe at elevated carbon dioxide due to higher tissue temperatures. Agricultural and forest meteorology, 139: 237-251.

Prasad PV, Pisipati S, Mutava R, Tuinstra M. 2008. Sensitivity of grain sorghum to high temperature stress during reproductive development. Crop Science, 48: 1911-1917.

Quinby J, Hesketh J, Voigt R. 1973. Influence of temperature and photoperiod on floral initiation and leaf number in sorghum. Crop Science, 13: 243-246.

Rains GC, Cundiff J, Vaughan D. 1989. Development of a whole-stalk sweet sorghum harvester. Virginia Polytechnic Institute and State University.

Ramadan SIM. 2011. Effect of phosphorus fertilizer on growth and Brix value of four sweet sorghum [Sorghum bicolor (L.) Moench] genotypes. M.Sc. Thesis, Faculty of Agriculture University of Khartoum, Shambat. Sudan.

Reddy BV, Ramesh S, Kumar AA, Wani S, Ortiz R, Ceballos H, Sreedevi T. 2008. Bio-fuel crops research for energy security and rural development in developing countries. Bioenergy Research, 1: 248-258.

Saballos A. 2008. Development and utilization of sorghum as a bioenergy crop. Genetic Improvement of bioenergy crops. Springer.

Singh SP. 1985. Sources of cold tolerance in grain sorghum. Canadian journal of plant science, 65: 251-257.

Smith B, Reeves JRS. 1981. Sweet sorghum biomass: Part III. Cultivars and plant constituents. Sugar Azucar, 37-50.

Smith CW, Frederiksen RA. 2000. Sorghum: Origin, history, technology, and production, John Wiley \& Sons.

Smith G, Bagby M, Lewellan R, Doney D, Moore P, Hills F, Campbell L, Hogaboam G, Coe G. Freeman K. 1987. Evaluation of sweet sorghum for fermentable sugar production potential. Crop Science, 27: 788-793.

Thakur P, Kumar S, Malik JA, Berger JD, Nayyar H. 2010. Cold stress effects on reproductive development in grain crops: an overview. Environmental and Experimental Botany, 67: 429-443.

Tiryaki I, Andrews DJ. 2001. Germination and seedling cold tolerance in sorghum. Agronomy journal, 93: 1391-1397.

Tsuchihashi N, Goto Y. 2004. Cultivation of sweet sorghum (Sorghum bicolor (L.) Moench) and determination of its harvest time to make use as the raw material for fermentation, practiced during rainy season in dry land of Indonesia. Plant Production Science, 7: 442-448.

Wardlaw IF, Bagnall D. 1981. Phloem transport and the regulation of growth of Sorghum bicolor (Moench) at low temperature. Plant physiology, 68: 411-414.

Wortmann CS, Regassa T. 2011. Sweet sorghum as a bioenergy crop for the US Great Plains, Intech Open Access Publisher Rijeka, Croatia.

Wright L, Turhollow A. 2010. Switch grass selection as a "model" bioenergy crop: a history of the process. Biomass and Bioenergy, 34: 851-868.

Zinn KE, Tunc-Ozdemir M, Harper JF. 2010. Temperature stress and plant sexual reproduction: uncovering the weakest links. Journal of Experimental Botany, 61: 1959-1968. 